\title{
Development of a Scientific and Innovative Sphere in Earth Resources Mining Sector of Kazakhstan
}

\author{
Nurlan Kurmanov ${ }^{1}$, Mariana Petrova $^{2, *}$, Shakhizada Suleimenova ${ }^{1}$ \\ ${ }^{1}$ L.N. Gumilyov Eurasian national university, Satpayev Str., 2, Nur-Sultan, Republic of Kazakhstan, \\ 010008 \\ ${ }^{2}$ St. Cyril and St. Methodius University of Veliko Tarnovo, Veliko Tarnovo, Bulgaria
}

\begin{abstract}
The article evaluates current trends in the development of science and innovation in Kazakhstan. Analysis of scientific and innovation activities in Kazakhstan show that among the main sources of financing science there are almost no business representatives. An assessment of the current state of the national innovation system demonstrates that with the existing system of financing science in Kazakhstan there is no possibility to increase the costs of research and development. The overall reduction in domestic R\&D expenditures over the period analyzed had the most negative impact on the financing of basic research. The results of the study show the need to revise some of the value settings for building a national innovation system in Kazakhstan.
\end{abstract}

\section{Introduction}

The rapid development of knowledge-intensive industries, the acceleration of the introduction of innovative scientific developments into mass production, the reduction of industrial equipment renewal cycles, the ongoing processes of informatization of the economy, changing employers' requirements for training and retraining specialists in content and structure, place new demands on science and innovative entrepreneurship. Under these conditions, the sphere of science and innovative entrepreneurship is no longer able to effectively adapt and develop to changes in isolation, independently of each other. A lot of businesses are looking for innovative ways to improve efficiency and maintain competitive advantage in order to survive $[1,2]$. Domestic and foreign researchers note that in an innovative economy, the efficiency and effectiveness of the interaction of economic actor's increases significantly from the organization of integration processes as a condition for the effective functioning of the management system of complex social and economic systems [3].

The main purpose of the article is to assess the current state and trends in the development of science, education and innovation in Kazakhstan.

\footnotetext{
*Corresponding author: m.petrova@ts.uni-vt.bg
} 


\section{Materials and methods}

At the first stage of the study of the state of science and innovative entrepreneurship in Kazakhstan, it seems appropriate to use methods of collecting, systematizing and analyzing literary sources.

Further, the official statistics of the Committee on Statistics of the Ministry of National Economy of the Republic of Kazakhstan should be used, since they will help characterize the current state of science and innovative entrepreneurship in Kazakhstan. To identify differences in the development of the main elements of the national innovation system science and innovative entrepreneurship - it is advisable to use the comparison method.

In our view, also in the study is necessary to use graphical methods, as they are used for visualizing the functional dependencies, to quickly find the values of the functions at the appropriate value of the argument.

\section{Results and discussion}

On the need to transfer the economy of Kazakhstan to the innovative way of development and the creation of a national innovation system is stated in the Strategy «Kazakhstan2050» [4] and the State Program for the Industrial-Innovative Development of the country until 2019 [5]. The knowledge economy is characterized by an increasing role of science, education, and innovative entrepreneurship in the development of society.

Let us analyze current trends in science and innovation in Kazakhstan.

In 2017, according to the Statistics Committee of the Ministry of National Economy in the Republic of Kazakhstan, 386 organizations were engaged in research and development, which is 45 units more compared to 2013 (341 organizations) (Table 1).

Table 1. Total number of organizations performing research and development, by sector of activity, 2013-2017, units.

\begin{tabular}{|c|c|c|c|c|c|c|}
\hline \multirow{2}{*}{ Organizations } & \multicolumn{5}{|c|}{ Years } & \multirow{2}{*}{$\begin{array}{c}\text { Modification } \\
\mathbf{2 0 1 7 / 2 0 1 3} \\
(+/-)\end{array}$} \\
\hline & 2013 & 2014 & 2015 & 2016 & 2017 & \\
\hline $\begin{array}{l}\text { Entrepreneurship } \\
\text { sector }\end{array}$ & 110 & 149 & 154 & 149 & 146 & +36 \\
\hline $\begin{array}{l}\text { Higher education } \\
\text { sector }\end{array}$ & 112 & 105 & 103 & 103 & 99 & -13 \\
\hline Government sector & 78 & 101 & 94 & 100 & 101 & +23 \\
\hline Non-profit sector & 41 & 37 & 39 & 31 & 40 & -1 \\
\hline Total & 341 & 392 & 390 & 383 & 386 & 45 \\
\hline
\end{tabular}

Despite the intensive development of a network of scientific organizations in the city of Nur-Sultan, the city of Almaty continues to be the leading scientific center of Kazakhstan. In 2017 , in the city of Almaty, about $1 / 3$ of all organizations in Kazakhstan were engaged in research and development.

The data in Table 1 indicate that, out of the total number of scientific organizations, $38 \%$ belonged to the entrepreneurial sector of the national economy, which includes enterprises and organizations whose activities are related to the production of products or services for sale.

Compared to 2013, the number of organizations in the business sector increased by 36 units, but compared to 2016, their number decreased by three units. 
The higher education sector is the second in number of scientific organizations. The sector of higher vocational education includes higher educational institutions, regardless of their legal status, the source of their funding, associated with them, or experimental stations and clinics under their control, and research institutes. In 2017, out of the total number of organizations in this sector, 99 organizations were engaged in research and development. The number of organizations in the sector of higher vocational education decreased by 13 units compared to 2013, in 2017 their number decreased by 4 units compared to 2016. In our opinion, this is connected with the ongoing policy of the state to reduce the number of higher educational institutions in the country.

The public sector is represented by ministries and departments that meet the needs of society and the public administration system. This sector also includes non-profit organizations mainly or fully funded and controlled by the state.

The number of organizations in this sector has an extensive network of research and development organizations.

Their number is not stable and varies from year to year. In 2017, for example, 101 public sector organizations conducted research and development. This is 23 units more compared to 2013.

In 2017, the smallest number of organizations performing research and development is represented in the non-profit sector of science. This sector includes organizations that do not aim to make a profit (public organizations, professional societies, foundations, etc.) and private individual organizations, in 2017 - 40 units.

Thus, in 2017 compared to 2013, the reduction in organizations occurred in the nonprofit and higher education sectors, respectively, by 1 and 13 units.

If we consider the types of organizations performing research and development, we can note a characteristic trend.

More and more institutions of higher education in Kazakhstan are engaged in research and development (R\&D).

So, by the end of 2017,89 universities of the country, along with the main educational activities, carried out research. However, at the same time in the country there is a reduction in the network of research institutes (SRI) (Table 2).

Table 2. Total number of organizations performing research and development, by type of organization, 2013-2017, units.

\begin{tabular}{|c|c|c|c|c|c|c|}
\hline \multirow{2}{*}{ Organizations } & \multicolumn{7}{|c|}{ Years } & $\begin{array}{c}\text { Modificatio } \\
\text { n 2017/2013 } \\
(+/-)\end{array}$ \\
\cline { 2 - 6 } & $\mathbf{2 0 1 3}$ & $\mathbf{2 0 1 4}$ & $\mathbf{2 0 1 5}$ & $\mathbf{2 0 1 6}$ & $\mathbf{2 0 1 7}$ & -1 \\
\hline SRI & 231 & 245 & 237 & 225 & 230 & +5 \\
\hline Universities & 84 & 89 & 90 & 93 & 89 & +41 \\
\hline Other organizations & 26 & 58 & 63 & 65 & 67 & 45 \\
\hline Total & 341 & 392 & 390 & 383 & 386 & r \\
\hline Note - the table is compiled according to the Committee on Statistics of the MNE RK \\
\hline
\end{tabular}

The data in Table 2 shows that in 2017 there was a reduction of the number of research institutions by 1 unit compared to 2013. The positive dynamics with the 2013 - 2017 years there has been on other types of institutions - universities and other organizations.

In 2017, 22,081 people were involved in research and development, including 17,205 research researchers (Figure 1). 


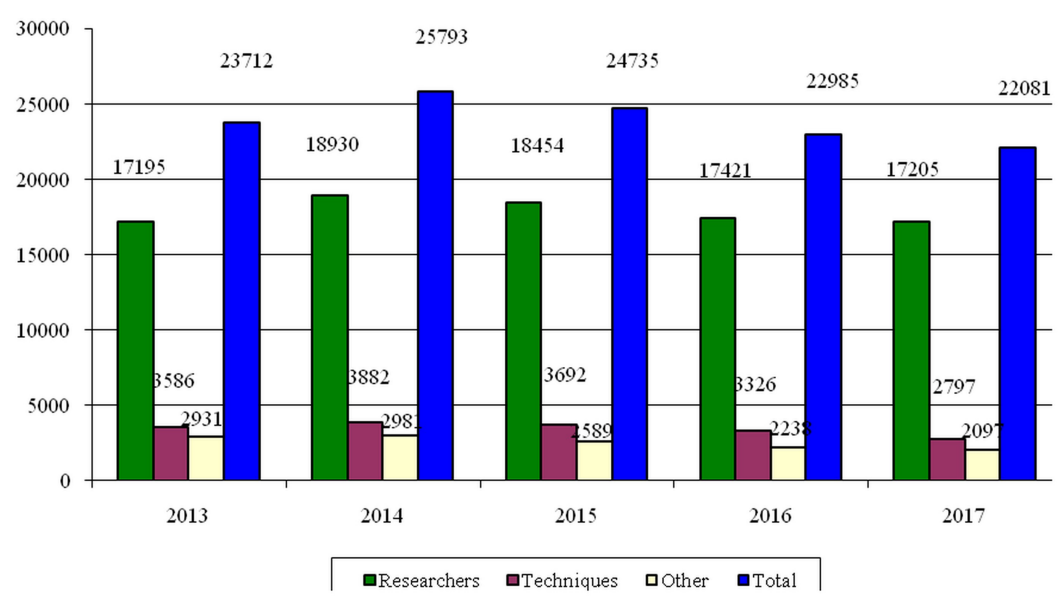

Fig.1. The personnel involved in carrying out research and development.

Note - the figure was compiled according to the Statistics Committee of the MNE RK.

In general, as can be seen from the data in Figure 1, from 2013 to 2014 the dynamics of the number of personnel engaged in research and development is positive. However, since 2015, the field of science in Kazakhstan has suffered a drastic reduction of staff against the background of the intensification of the crisis in the economy and, as a consequence, a reduction in the level of wages. Also, it should be noted that the reduction of personnel in the research field of Kazakhstan is following the decrease in the contribution of the industry to economic growth.

According to experts $[6-8,9-10,12]$, the factors limiting the innovation activities of the business sector are:

a) low innovative potential (lack of competent personnel, lack of funds for the development of innovative entrepreneurship);

b) not necessary due to the lack of demand for innovation.

In this regard, we will study in more detail the problem of organizing the financing of research and development carried out from the public budget and the private sector. In order to analyze the mechanism of the possibility of increasing the knowledgeintensiveness of GDP in Kazakhstan (an indicator reflecting the existing proportion between scientific and technical activities in the form of costs and GDP), their structure should be analyzed (Table 3 ).

Table 3. Domestic current R\&D expenditures by sector of activity, 2013-2017, mln. Tenge.

\begin{tabular}{|l|c|c|c|c|l|l|}
\hline \multirow{2}{*}{ Organizations } & \multicolumn{5}{|c|}{ Years } & $\begin{array}{l}\text { Modification } \\
2017 / 2013 \\
(+/-)\end{array}$ \\
\cline { 2 - 7 } & $\mathbf{2 0 1 3}$ & $\mathbf{2 0 1 4}$ & $\mathbf{2 0 1 5}$ & $\mathbf{2 0 1 6}$ & $\mathbf{2 0 1 7}$ & \\
\hline $\begin{array}{l}\text { Entrepreneurship } \\
\text { sector }\end{array}$ & 18150.9 & 24337.6 & 27790.8 & 28872.7 & 28665 & +10514.1 \\
\hline $\begin{array}{l}\text { Higher } \\
\text { education sector }\end{array}$ & 18926.1 & 14706.5 & 13485 & 11532.1 & 13179.5 & -5746.6 \\
\hline $\begin{array}{l}\text { Government } \\
\text { sector }\end{array}$ & 18304.4 & 21695.6 & 20325.8 & 18640.4 & 20961.4 & +336 \\
\hline $\begin{array}{l}\text { Non-profit } \\
\text { sector }\end{array}$ & 6291.3 & 5607.9 & 7701.3 & 7555 & 6078.2 & +2657 \\
\hline Total & 61672.7 & 66347.6 & 69302.9 & 66600.1 & 68884.2 & +7211.5 \\
\hline Note - the table is compiled according to the Committee on Statistics of the MNE RK \\
\hline
\end{tabular}


According to the Statistics Committee of the Ministry of National Economy of the Republic of Kazakhstan, in 2017 the largest share in the structure of domestic R\&D expenditures accounted for wages - $50 \%$.

For all categories of workers in the field of science, the main source of wage payments is the wage fund, which is formed at the expense of the cost of research projects.

Figure 2 shows the share of major sources of funding in total R \& D costs.

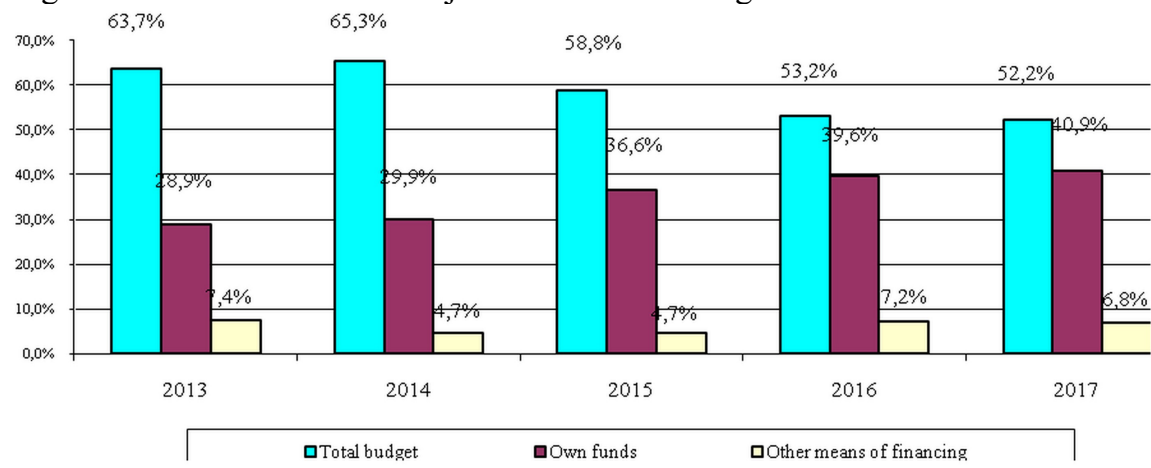

Fig. 2. The share of the main sources of funding in the total cost of $R \& D, \%$.

Note - the figure was compiled according to the Statistics Committee of the MNE RK

In 2017, the reduction of budget funds for financing science forced the scientific organizations themselves to more actively use their own funds. As a result, in 2017 compared to 2015 , the share of financing from own sources increased by $11.7 \%$. In addition, the decline in government $R \& D$ expenditures has forced research and development organizations to look for other sources of research funding, such as loans, loans, whose share has increased by $44.6 \%$.

Among the main sources of financing science there are almost no business representatives representing the real sector of the economy of Kazakhstan. It should be noted that, according to the OECD, at present, for American and European companies, the share of the real sector of the economy in total spending on research and development at the level of $60-65 \%$ is optimal. At the same time, the financing of R\&D in many developed countries of the world is currently at the level of $60-75 \%$ carried out by the business sector of the national economy [9].

Thus, an analysis of R\&D costs indicates that under the existing system of financing science in Kazakhstan there is no possibility to increase the costs of research and development.

In addition, the manufacturing sector, which is the main consumer of research and development, has been reducing its activity recently. This affects the loss of real production, bringing foreign exchange earnings to the state budget and forming tax revenues and serving as a source of financing science in the country. The share of production (goods) by the end of 2017 in GDP was 36\%.

In 2017, the sector of higher vocational education turned out to be the most affected by the reduction of domestic $R \& D$ expenditures: the costs in this sector were reduced by $43.6 \%[10,11]$.

Figure 3 presents data on domestic R\&D expenditures by type of research and development. 


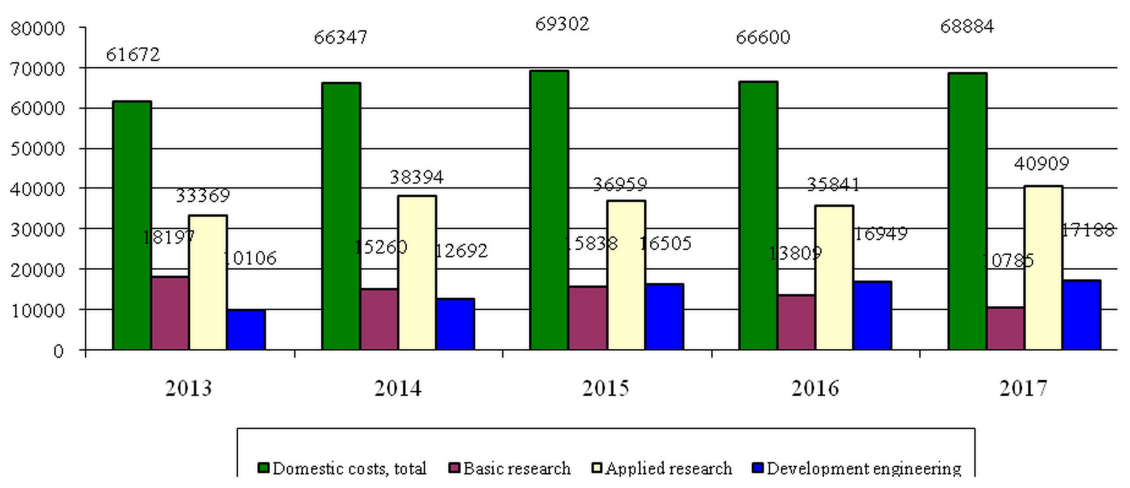

Fig.3. Domestic costs of R\&D by type of research from 2013 to 2017, million tenge.

Note - the figure was compiled according to the Statistics Committee of the MNE RK

The data in Figure 3 show that the overall reduction in domestic R\&D expenditures had the most negative impact on the funding of basic research. In 2017 compared to 2013, their volume decreased by $59.2 \%$. It should be noted that in this period the costs of applied research and development work increased.

\section{Summary}

Thus, we can draw the following main conclusions: Knowledge-based GDP has a multiplier effect. The country's GDP will grow at a larger rate with an increase in investment in science than the initial cash investment. In addition to the primary effect, subsequent effects occur. In this regard, most countries in the world are interested in increasing public and private investment in science, and those countries in which the knowledge-intensiveness of GDP exceeds 3\% are in the forefront of technological progress.

Among the main sources of funding of science are almost no representatives of business, representing the real sector of economy of Kazakhstan. According to the OECD, at present, for American and European companies, the share of the real sector of the economy in total expenditure on research and development at the level of $60-65 \%$ is optimal. At the same time, the financing of R \& D in many developed countries of the world is currently at the level of $60-75 \%$ carried out by the business sector of the national economy.

An analysis of the costs of R\&D shows that with the existing system of financing science in Kazakhstan there is no possibility to increase the costs of research and development. The overall reduction in domestic R\&D expenditures over the period analyzed had the most negative impact on the financing of basic research. In addition, the manufacturing sector, which is the main consumer of research and development, has been reducing its activity recently.

In the current situation, we believe that it is necessary to strengthen the relationship of science with the real economy, the commercialization of the results of scientific activity on the basis of public-private partnership.

\section{References}

1. M. Petrova, M. Tepavicharova, L. Boykova, E3S Web Conf., 41, 04017 (2018). 
2. M. Petrova, N. Dekhtyar, O. Klok, O.Loseva, Problems and Perspectives in Management, 16:4, 259-274 (2018)

3. R. Pukala, Engineering Management in Production and Services, 8:3, $43-56$ (2016)

4. "Strategy" Kazakhstan-2050": a new political course of the established state, URL: http://www.akorda.kz/ru/events/astana_kazakhstan/

5. Decree of the President of the Republic of Kazakhstan dated August 1, 2014 No. 874 "On approval of the State program of industrial-innovative development of the Republic of Kazakhstan for 2015-2019, URL: https://online.zakon.kz/Document/?doc_id $=31588425$

6. N. Kurmanov, B. Tolysbayev, D. Aibossynova, N. Parmanov, Ekonomichnij chasopisXXI, 158, 57-61 (2016) DOI: http://dx.doi.org/10.21003/ea.V158-13

7. N. Kurmanov, B. Beisengaliyev, A. Dogalov, D. Turekulova, N. Kurmankulova, International Journal of Economics and Financial Issues, 4, 1440-1445 (2016)

8. R. Pukala, S. Kaidarova, S. Makysh, K. Zhumanov, Proceedings of the 31st Conference IBIMA 2018, I:XI, 91-95 (2018)

9. P. Adamisin, R. Vavrek, R. Pukala, International Multidisciplinary Scientific GeoConference-SGEM, III, 135-140 (2015)

10. N.A. Kurmanov, A.N. Toksanova, A.A. Mukhamedzhanova, N.Sh. Syrlybaeva, M.M. Petrova, Bulletin of the Kazakh National University, 4:126, 35-51 (2018)

11. N. Kurmanov, A. Yeleussov, U. Aliyev, B. Tolysbayev, Mediterranean Journal of Social Sciences, 5, 54 (2015)

12. Sv. Labunska, M. Petrova, O. Prokopishyna, Economic Annals - XXI, 165:5-6, 13-18 (2017) DOI: https://doi.org/10.21003/ea.V165-03 